\title{
Prevalence Evaluation of Salivary Glucose and Total Proteins Levels in Children with Type I Diabetes
}

\author{
SANYA ABD EL HALIM FAHMY, M.D.; SOHEIR MAKLED, M.D. and NERMEEN M.F. HAIDER, M.D.
}

The Departments of Pediatric* and Microbiology \& Immunology**, Faculty of Medicine for Girls, Al-Azhar University and The Department of Pediatric, National Institute for Diabetes and Endocrinology***

\begin{abstract}
Background: Glucose can be found in normal indivduals saliva; however, its secretion mechanism is still not clear. Increased glucose content in salivary secretion was reported in diabetic patients by many authors as the salivary glands filter the blood glucose.

Aim of Study: The aim of this study was todetermine whether salivary glucose protein levels could be used as a noninvasive tool for diagnosis and glycemic control of type -1 diabetes in children.

Material and Methods: 200 patients with type $1 \mathrm{DM}$ their ages range from 5 to 18 years old randomly assigned into 2 groups: Control and study groups. Group 1: 100 child with type 1DM according to American Diabetes Association 2015. Group 2: (Control group) 100 child apparently healthy with the same age and sex matched children. Fasting blood glucose, Glycosylated $\mathrm{Hb}\left(\mathrm{HbA}_{1_{c}}\right)$, Salivary glucose and Salivary total proteins were measured.

Results: There was a significant difference between the two groups in glucose level measured by glucose level concentration in saliva which is higher in diabetic patients.

Conclusion: The present study confirmed that salivary glucose protein levels could be used as a noninvasive and non expensive tool for diagnosis and glycemic control of type -1 diabetes in children.
\end{abstract}

Key Words: Type-1 diabetes - Salivary glucose - Serum glucose - Salivary proteins $-\mathrm{HbA}_{1_{c}}$

\section{Introduction}

DIABETES Mellitus can be defined as a group of metabolic disorders which characterized by hyperglycemia with metabolic disturbance of carbohydrate, fat and protein because of either defects in insulin secretion, insulin action, or both. Many complications can be associated with long-term damage the chronic hyperglycemia of diabetes mellitus such as dysfunction, and failure of differ-

Correspondence to: Dr. Nermeen M.F. Haider, E-Mail: Dr.nermeenhaider@hotmail.com ent organ, especially the eyes, kidneys, nerves, heart, and blood vessels [1].

Type one diabetes is a multi factorial disease caused by the autoimmune dysfunction of insulin producing pancreatic 0 -cells, resulting in severe hyperglycemia leading to the dependence on external insulin replacement on a lifelong basis [2]

Diabetes is reported to have effect on the functions of the salivary gland leading to altering the saliva composition [3].

People with diabetes san be monitored through repeated calculation of plasma glucose by finger pricks and also intravenous blood sampling. However, glucose measurement through a noninvasive procedure is considered the most precious under the circumstances. So, Saliva isreported as unique and complex body fluids asplasma or serum. Saliva is easily to be collected through noninvasive methods and its preservation is not expensive. The diagnostic value of saliva depends onthe gland components, flow and structure [4].

\section{Material and Methods}

200 patients with type $1 \mathrm{DM}$, their ages range from 5 to 18 years old randomly assigned into 2 groups: Control and study groups. Group 1: 100 child with type $1 \mathrm{DM}$ according to American Diabetes Association 2015 following criteria (FBG $>126 \mathrm{mg} / \mathrm{dl}$ or 2 -hour $\mathrm{PG}>200 \mathrm{mg} / \mathrm{dl}$ or $\mathrm{A} 1 \mathrm{C}>6.5 \%$ or random plasma glucose $>200 \mathrm{mg} / \mathrm{dl}$ with classic symptoms of hyperglycemia or hyperglycemic crises). They were selected from children attending the outpatient Pediatric Diabetic Clinic of the National Diabetic Institute during regular followup during the period from January 2015 to December 2015. Informed written consents were obtained from parients of each childfor their agreement for participation in the study. 
Subgroup 1: Controlled patients: Consisted of 48 controlled diabetics whose random nonfasting plasma glucose levels were in the range of 120 $200 \mathrm{mg} / \mathrm{dl}$.

Subgroup 2: Uncontrolled patients: Consisted of 52 uncontrolled diabetics whose random non fasting plasma glucose levels greater than 200 $\mathrm{mg} / \mathrm{dl}$.

Children with chronic diseases or chronic infections (chronic autoimmune hepatitis, chronic hematologic disorders, prolonged malnutrition, cancer), presence of oral cavity diseases such as: Oropharyngeal candidiasis, oral bacterial infections: As periodontitis, dental carries, or oral viral infections, age younger than 5 years, children with type II DM were excluded from participation in the study.

Group 2: (Control group) 100 child apparently healthy with the same age and sex matched children.

A full medical history with demographic data of name, age, sex and socioeconomic class, age at onset of diabetes (disease duration), insulin therapy regarding type, dose and frequency, degree of response to treatment and glycosylated hemoglobin, history of acute diabetic complications were recorded.

Clinical examination was done including anthropometric measures: Weight in $\mathrm{Kg}$ and height in $\mathrm{cm}$ were plotted against percentiles for age and sex according to Egyptian growth charts and body mass index was calculated by applying the following formula:

$$
\mathrm{BMI}=\frac{\text { Weight in } \mathrm{Kg}}{\text { Height in } \mathrm{m}^{2}}
$$

\section{Laboratory investigations:}

1- Fasting blood glucose measurement.

Fasting blood glucose levels were measured through the method of Glucose Oxidase-Peroxidase (GOD-POD) end point.

2- Glycosylated $\mathrm{Hb}\left(\mathrm{HbA}_{l_{\mathrm{c}}}\right)$ : To measure the average blood glucose concentration over an extended period of time.

Using quantitative calorimetric estimation of glycated hemoglobin in the whole blood, according to micro-chromatographic assay method which was described by [5]. Patients were considered to be of optimal normal glycemic control if $\mathrm{HbA}_{1 \mathrm{c}}$ was $<7.5 \%$ and patients were considered of high risk with $\mathrm{HbA} 1 \mathrm{c}>7.5 \%$ [6].
3- Salivary glucose was estimated through glucose oxidase end point method.

4- Salivary total proteins measurement through Bradford method [7].

All patients should be fasting till both blood and salivary samples were collected.

\section{1-Saliva samples:}

The unstimulated whole saliva was collected at one sitting for estimation of glucose and total protein levels by spitting method. The patients and controls were asked to sit erect with the head tilted forward and instructed not to speak or do any movements of the head such as wallowing either swallowing any saliva or if present in the mouth during the procedure. Then they were instructed to rinse the mouth thoroughly with water twice. Two millimeters of the generated saliva in mouth was spit in a sterile plastic graduated container every minute for 10 minutes and stored over the ice. Then saliva were centrifuged at $3000 \mathrm{rpm}$ for four minutes. The centrifuged saliva was splited into two equal parts. One part was used for glucose level estimation while, the second part was stored at the temperature of $20 \mathrm{c}$ till used for protein level.

\section{2- Blood samples:}

All blood samples were carefully collected immediately in the same sitting directly after salivary samples to avoid any alteration of the glucose level.

Centrifuge of three $\mathrm{ml}$ of venous blood that were taken without anticoagulant was done to separate cells and sera in order to be used to examine glucose and $\mathrm{HbA}_{l_{\mathrm{c}}}$

Glucose Oxidase-Peroxidase (GOD-POD) method, end point was used for the measurement of both serum and salivary glucose levels. The collected salivary samples were centrifuged for 3 minutes at $3000 \mathrm{rpm} .5 \mathrm{gl}$ were mixed with $500 \mathrm{gl}$ of GOD-POD reagent and incubated for 5 minutes at the temperature of $37 \mathrm{c}$. The glucose levels were recorded through placing the incubated samples in auto analyzer.

Total levelsof salivary protein were measured through the use of Bradford protein assay [7] .

\section{Statistical analysis:}

A statistical package program was used to evaluate the data obtained from the study (statistical program for social science, version 11.0). Descriptive statistical methods (frequency, proportion, 
mean, and standard deviation) were used in the evaluation of research data. The Pearson chi-square test was used in comparing qualitative data. Correlation coefficince test was used to examine correlation between between salivary and serum glucose levels in the diabetic group and also correlation between total salivary proteins in both diabetic and control groups.

In comparing quantitative data, the unpaired samples $t$-test was used in inter group comparison of parameters. The paired samples $t$-test was used for intra group comparisons. The results were calculated at the $95 \%$ confidence interval, $p<0.05$ significance level and $p<0.01$ advanced significance level.

\section{Results}

No study participant left the research project for any reason. No side effects or complications were observed during the study period. Baseline characteristics of the patients are shown in (Table 1). No statistically significant difference was found between the 2 groups in terms of age, sex and family history $(p>0.05)$. Most of diabetic patients were from urban regions $(70 \%)$ while $(30 \%)$ were from rural areas which was of highly significant difference $(p<0.001)$.

There is a highly significant difference between both groups regarding both serum and salivary glucose levels $(p<0.001)$, as shown in (Table 2$)$.

Total salivary proteins levels are highly statistically significant in patients group than in normal group $(p<0.001)$, asshown in (Table 3$)$.

Table (4) and Figs. (1-5) show that there were highly significant positive correlation observed between salivary and serum glucose levels in the diabetic group ( $r=0.880$ and $p<0.001)$, between serum glucose and $\mathrm{HbA} 1 \mathrm{C}$ in diabetic group ( $r=$ 0.536 and $p<0.001$ ), between serum glucose and salivary total protein levels ( $r=0.795$ and $p<0.001$ ), between salivary glucose and $\mathrm{HbA}_{1 \mathrm{C}}(r=0.596$ and $p<0.001$ ), and between salivary glucose and salivary total protein levels ( $r=0.800$ and $p<0.001)$, as shown in (Table 5) and Figs. (1-5).

Both serum and salivary glucose levels are higher in patient group (controlled, uncontrolled) than normal group with a highly statistically significant difference $(p<0.001)$, as shown in (Table $5)$.

The salivary total proteins levels are higher in patients subgroup (controlled, uncontrolled) than in normal group with highly statistically significant difference $(p<0.001)$, as shown in (Table 6).

Table (1): Demographic data of diabetic patients and controls.

\begin{tabular}{|c|c|c|c|}
\hline & $\begin{array}{l}\text { Normal group } \\
\text { No. }=100\end{array}$ & $\begin{array}{l}\text { Patient group } \\
\text { No. }=100\end{array}$ & $p$-value \\
\hline \multicolumn{4}{|l|}{ Age: } \\
\hline Mean \pm SD & $\begin{array}{l}9.84 \pm 2.93 \\
\text { (range 5-16) }\end{array}$ & $\begin{array}{l}10.31 \pm 3.36 \\
(\text { range } 5-18)\end{array}$ & $0.298 \mathrm{NS}$ \\
\hline $\begin{array}{l}\text { Female } \% \\
\text { Male } \%\end{array}$ & $\begin{array}{l}46(46.0 \%) \\
54(54.0 \%)\end{array}$ & $\begin{array}{l}49(49.0 \%) \\
51(51.0 \%)\end{array}$ & $0.671 \mathrm{NS}$ \\
\hline $\begin{array}{r}\text { Residence: } \\
\text { Rural \% } \\
\text { Urban \% }\end{array}$ & $\begin{array}{ll}0 & (0.0 \%) \\
100 & (100.0 \%)\end{array}$ & $\begin{array}{l}30(30.0 \%) \\
70(70.0 \%)\end{array}$ & $0.000 * *$ \\
\hline $\begin{array}{c}\text { Family history } \\
\text { Negative } \% \\
\text { Positive } \%\end{array}$ & $\begin{array}{c}90(90.0 \%) \\
10(10.0 \%)\end{array}$ & $\begin{array}{l}83(83.0 \%) \\
17(17.0 \%)\end{array}$ & $0.147 \mathrm{NS}$ \\
\hline
\end{tabular}

$p$-value $>0.05$ : Non significant (NS).

$* * p$-value $<0.01$ : Highly significant.

Table (2): Comparison between glucose levels ( $\mathrm{mg} / \mathrm{dl})$ in serum and saliva in both patients and control groups.

\begin{tabular}{cccc}
\hline & $\begin{array}{c}\text { Normal group } \\
\text { No. }=100\end{array}$ & $\begin{array}{c}\text { Patient group } \\
\text { No.=100 }\end{array}$ & $p$-value \\
\hline $\begin{array}{c}\text { Serum glu } \mathrm{mg} / \mathrm{dl}: \\
\text { Median (IQR) }\end{array}$ & 85 & & \\
& $(71-96.5)$ & $(134.5-0.307)$ & \\
Range & $61-118$ & $72-569$ & \\
& & & \\
Salivary glu mg/dl: & & & \\
Median (IQR) & 0.095 & 0.468 & $0.000 * *$ \\
& $(0.083-0.109)$ & $(0.218-0.66)$ & \\
Range & $0.064-0.142$ & $0.07-1.597$ & \\
\hline
\end{tabular}

$* * p$-value $<0.01$ : Highly significant

Table (3): Total salivary proteins in both patients and normal groups.

\begin{tabular}{llll}
\hline Salivary T.S.P & $\begin{array}{c}\text { Normal group } \\
\text { No.=100 }\end{array}$ & \multicolumn{1}{c}{$\begin{array}{c}\text { Patient group } \\
\text { No.=100 }\end{array}$} & $p$-value \\
\hline Median (IQR) & $\begin{array}{l}\text { 6.95 (3.7-14.4) } \\
\text { Range }\end{array}$ & $\begin{array}{l}39(27.9-63.75) \\
13-150\end{array}$ & $.000 * *$ \\
\hline
\end{tabular}

** $=p$-value <0.01: Highly significant.

T.S.P.: Total Salivary Proteins.

Table (4): Correlation coefficent between serum and, salivary glucose levels, age, $\mathrm{HbA}_{1 \mathrm{C}}$ and salivary total salivary protein in diabetic group.

\begin{tabular}{lclcc}
\hline & \multicolumn{2}{c}{ Serum glu } & \multicolumn{2}{c}{ Salivary glu } \\
\cline { 2 - 5 } & $r$ & $p$-value & $r$ & $p$-value \\
\hline Serum glu & & & 0.880 & $0.000^{* *}$ \\
Salivary glu & 0.880 & $0.000^{* *}$ & & \\
Age & 0.174 & $0.084 \mathrm{NS}$ & 0.178 & $0.076 \mathrm{NS}$ \\
HbA1C & 0.536 & $0.000^{* *}$ & 0.596 & $0.000^{* *}$ \\
Salivary T.S.R & 0.795 & $0.000^{* *}$ & 0.800 & $0.000^{* *}$ \\
\hline
\end{tabular}

$p$-value $>0.05$ : Non Significant (NS).

**: $p$-value <0.01: Highly significant. 
Table (5): Serum and salivary glucose levels $(\mathrm{mg} / \mathrm{dl})$ in controlled, uncontrolled diabetic patients and normal controls.

\begin{tabular}{|c|c|c|c|c|}
\hline & $\begin{array}{l}\text { Normal } \\
\text { group } \\
\text { No. }=100\end{array}$ & $\begin{array}{l}\text { Controlled } \\
\text { group } \\
\text { No.=48 }\end{array}$ & $\begin{array}{c}\text { Uncontrolled } \\
\text { group } \\
\text { No.=52 }\end{array}$ & $\begin{array}{c}p- \\
\text { value }\end{array}$ \\
\hline \multicolumn{5}{|l|}{$\begin{array}{l}\text { Serum glu } \\
(\mathrm{mg} / \mathrm{dl}) \text { : }\end{array}$} \\
\hline Median (IQR) & $\begin{array}{c}85 \\
(71-96.5)\end{array}$ & $\begin{array}{c}129.5 \\
(107-160)\end{array}$ & $\begin{array}{c}304.5 \\
(259-356.5)\end{array}$ & \multirow[t]{2}{*}{$.000 * *$} \\
\hline Range & $61-118$ & $72-199$ & $202-569$ & \\
\hline \multicolumn{5}{|l|}{$\begin{array}{l}\text { Salivary glu } \\
(\mathrm{mg} / \mathrm{dl}):\end{array}$} \\
\hline \multirow{2}{*}{ Median (IQR) } & \multirow{2}{*}{$\begin{array}{c}0.095 \\
(0.083-0.109)\end{array}$} & \multirow{2}{*}{$\begin{array}{c}0.21 \\
(0.132-0.281)\end{array}$} & \multirow{3}{*}{$\begin{array}{c}0.654 \\
(0.525-0.713) \\
0.273-1.597\end{array}$} & \multirow[t]{3}{*}{$.000^{* * *}$} \\
\hline & & & & \\
\hline Range & $0.064-0.142$ & $0.07-0.661$ & & \\
\hline \multicolumn{5}{|c|}{$\begin{array}{l}p \text {-value }>0.05: \text { Non significant }(\mathrm{NS}) . p \text {-value }<0.05 \text { : Significant }(\mathrm{S}) \text {. } \\
p \text {-value }<0.01 \text { : Highly significant }(\mathrm{HS}) .\end{array}$} \\
\hline \multicolumn{5}{|c|}{$\begin{array}{l}\text { Table (6): } \text { HbA }_{1 C} \text { and salivary total proteins in controlled, } \\
\text { uncontrolled patients and normal controls. }\end{array}$} \\
\hline & $\begin{array}{l}\text { Normal } \\
\text { group } \\
\text { No. }=100\end{array}$ & $\begin{array}{c}\text { Controlled } \\
\text { group } \\
\text { No. }=48\end{array}$ & $\begin{array}{c}\text { Uncontrolled } \\
\text { group } \\
\text { No. }=52\end{array}$ & $\begin{array}{c}p- \\
\text { value }\end{array}$ \\
\hline \multicolumn{5}{|l|}{ HbAlC: } \\
\hline Mean \pm SD & & $8.76 \pm 2.59$ & $11.50 \pm 2.48$ & \multirow[t]{2}{*}{$.000 * *$} \\
\hline Range & & $4.5-15.1$ & $6.8-16$ & \\
\hline \multicolumn{5}{|l|}{ Salivary T.S.P: } \\
\hline Median (IQR) & $\begin{array}{c}6.95 \\
(3.7-14.4)\end{array}$ & $\begin{array}{c}27.9 \\
(21.8-33)\end{array}$ & $\begin{array}{c}58 \\
(45.75-72.2)\end{array}$ & \multirow[t]{2}{*}{$.000^{* * *}$} \\
\hline Range & $1.5-47$ & $15-66.9$ & $13-150$ & \\
\hline
\end{tabular}

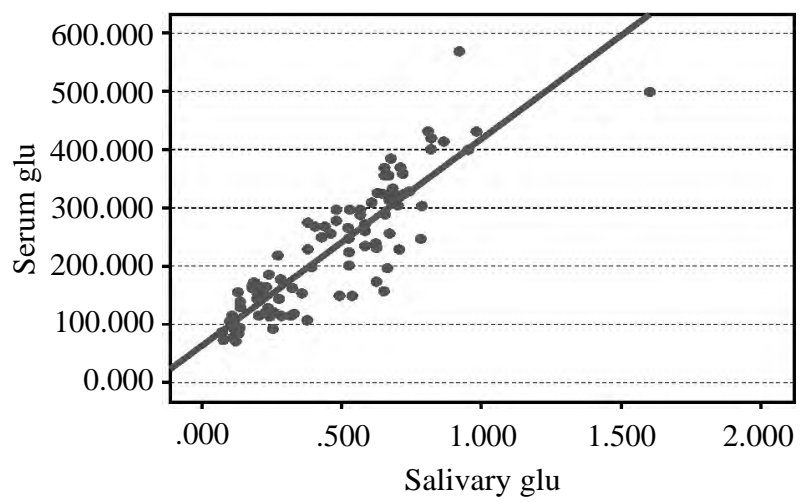

Fig. (1): Correlation between serum and salivary glucose in diabetic patients. $r=0.880, p<0.001$.

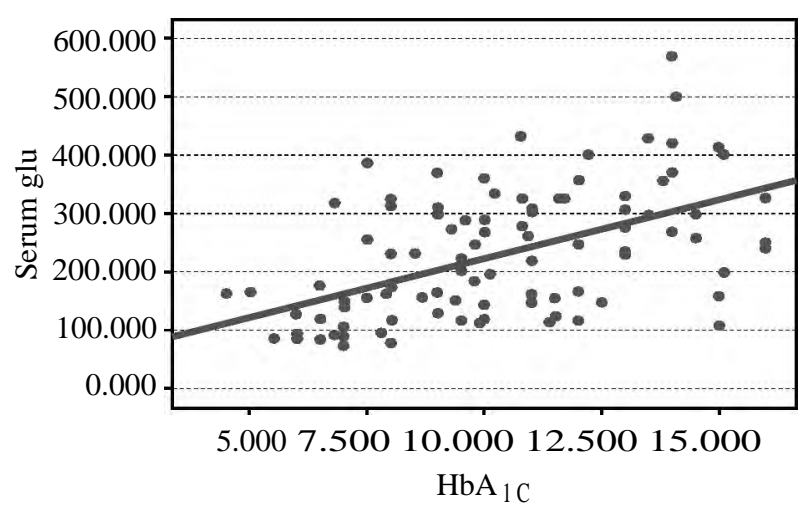

Fig. (2): Correlation between serum glucose and $\mathrm{HbA}_{1 \mathrm{c}}$ in diabetic patients. $r=0.536, p<0.001$.

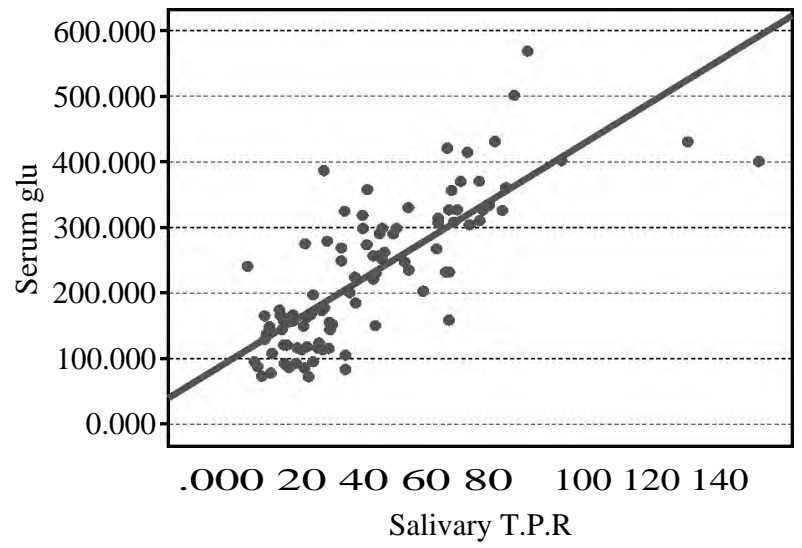

Fig. (3): Correlation between serum glucose and salivary total protein in diabetic patients. $r=0.795, p<0.001$.

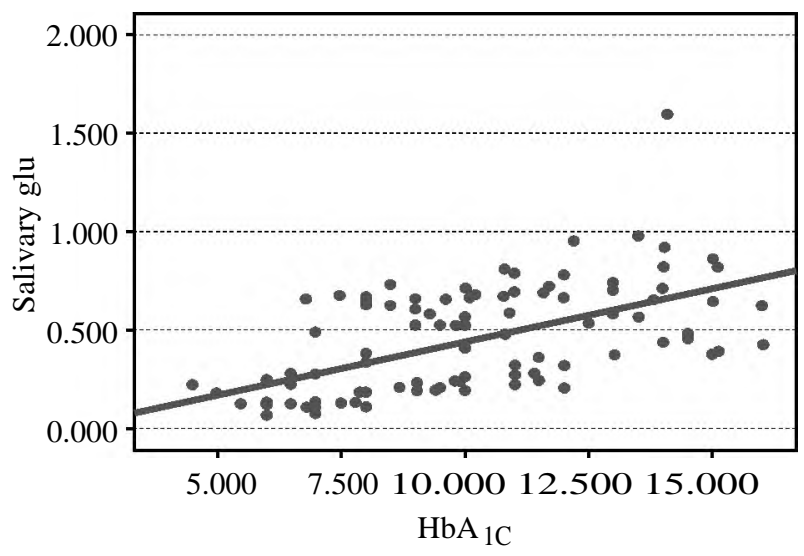

Fig. (4): Correlation between salivary glucose and $\mathrm{HbA}_{1_{C}}$ in diabetic patients. $r=0.596, p<0.001$.

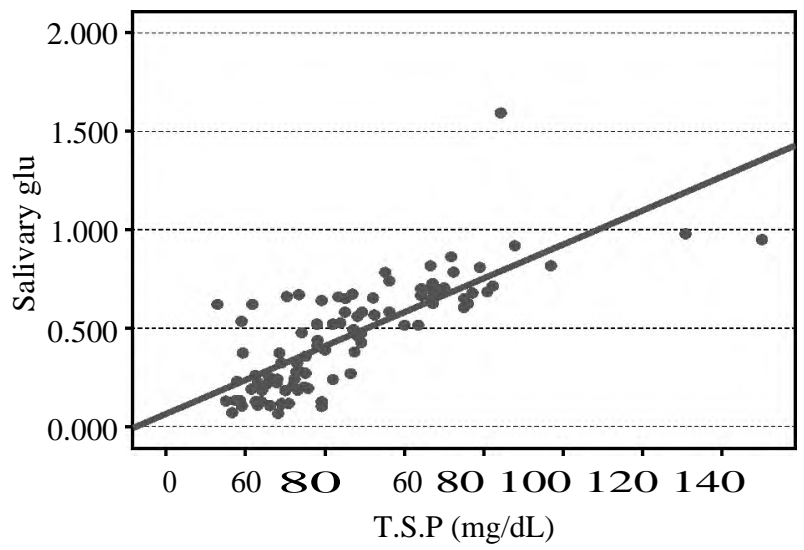

Fig. (5): Correlation between salivary glucose and salivary total protein in diabetic pateints. $r=0.800, p<0.001$.

\section{Discussion}

Diabetes Mellitus (DM) is a common endocrine disorder which is characterized by an alteration in insulin production leading consequent changes of the process of blood glucose concentration metabolism and balance [9]. 
Diagnosis of diabetes can be done only through measuring blood glucose levels either random, fasting and postprandial which all are considered physically and psychologically invasive traumatic methods to the patients. Therefore, there is a great need for noninvasive, simple, and painless procedure [10]

Saliva is considered a mirror of the blood because of many similarities of these bio-fluids and their molecular components share. Saliva is as a diagnostic bio-fluid using recent sdvanced technology used over the past decades and helped many researchers to develop saliva based technology for detecting the relation between health and many diseases [11]

The present study aim to prove that saliva as a noninvasive diagnostic tool can be used by measuring both serum and salivary glucose levels in diabetic patients and find a correlation between them, also measuring $\mathrm{HbA}_{1 \mathrm{c}}$ and total salivary proteins and find correlation between them and serum glucose levels in diabetic patients.

This current study was carried out on 200 children, classified into 2 groups: Group 1: Included 100 diabetic children with an already established diagnosis of T1DM and group 2: Control group included 100 apparently healthy children. Both salivary and serum samples were obtained at the same time to avoid any change in the glucose levels.

It was reported that serum and salivary glucose levels were highly significant than normal controls in diabetic patients $(p<0.001)$. Lopez, 2003 repored the presense of glucose in saliva of normal individuals, and also found that the saliva glucose concentration increase in patients with diabetes which has been explained by many authors that the salivary glands are considered filters of blood glucose which are altered by both hormonal and neural regulation [12]

The persistent hyperglycemia resulting in blood vessels microvascular changes and also salivary glands basement membrane alteration leading to increased leakage of glucose from the ductal cells of the salivary glands, so, increasing the content of glucose in saliva [13].

These result of the current study were consistent with the studies done by (Shahbaz et al., 2014; Nagalaxmi et al., 2011 and Iqbal et al., 2011) who reported that the salivary glucose levels in T1DM group were highly significant compared to control group [14-16].
However, the results of the present study disagree with Forbat et al., 1981 who shown that salivary glucose levels did not reflect blood glucose levels [17]

It was reported that $76.4 \%$ of patients with diabetes have normal range of salivary glucose levels. Glucose is a small particle which can be diffused through the semi permeable membrane and can be easily detected in the saliva especially with higher elevation of the blood glucose levels. Also, basement membrane alteration of the salivary glands that results in the leakage of glucose in saliva, any change in the basement membrane of blood vessels may lead to increased transfere of glucose into saliva $[3,15]$

Saliva offers a better noninvasive cost effective diagnostic approach over serum for the screening of a large population [11].

The results of the present study revealed that levels of salivary total protein were higher in T $1 \mathrm{DM}$ group as compared to control group $(p<0.001)$ which come in accordance with the previous studies achieved by various authors who documented that total salivary protein were higher in T $1 \mathrm{DM}$ group than the control group $[\mathbf{9 , 1 8}]$.

The elevated levels of saliva proteins in patients with diabetes could be explained by the presence of abnormal binding of serum proteins to the basement membranes of salivary gland which reflects the increased basement membrane that is often resulted from diabetes leading to increased passages of proteins from exocrine glands to their secretions [19]. However, few studies reported no significant difference between the diabetic patients and controls [20]. This contradiction of studies results may be due to differences in methodology and the patientsstatus of metabolic control.

This study found that there was a positive correlation between salivary and serum glucose levels in the diabetic group $(r=0.880$ and $p<0.001)$. This correlation was found to be statistically significant. Hence, salivary glucose levels appears to be reflection of serum glucose concentration in diabetic patients. Similar to the results of the present study is the studies done by $[\mathbf{1 4 , 2 1 , 2 2 ]}$. The last study included 30 diabetic patients diagnosed by T1DM, and a control group consisted of 30 healthy individuals, the authors reported a positive significant correlations between serum and salivary glucose levels found in both diabetic and control groups. In contrast to the results of the current study $[\mathbf{3 , 9 , 2 3 ]}$, reported no correlation found between salivary and serum glucose levels which may be 
due to the use of different types of methodology and examination techniques of saliva included the studies.

In addition, $\mathbf{H A}_{1 \mathrm{C}}$ is reported to be correlated positively with the salivary glucose level in diabetic patients at the present study $(r=0.596, p<0.001)$, which can be explained that blood glucose concentration is more elevated over an extended time period in diabetic group but the blood glucose concentration is normal in the control group over an extended time period suggesting that the control group are non-diabetic [24]. These results are in accordance with the studies done by $[\mathbf{1 3 , 2 5}]$ who reported positive and significant correlation between ${ }_{\mathbf{H A}_{1 \mathrm{C}}}$ and their salivary glucose level patients with diabeties.

The results of the current study disagree with Lopez et al., 2003 who reported that salivary glucose level was not correlated with $\mathrm{HA}_{1 \mathrm{C}}$ percentage [12].

\section{Conclusion:}

This study demonstrated that there was a significant difference between the two groups in glucose level measured by glucose level concentration in saliva which is higher in diabetic patients.

\section{Acknowledgment:}

Authors express appreciation to all patients participated in the study.

\section{References}

1- American Diabetes Association (ADA): Standards of medical care in diabetes. Diabetes Care, 37 (1): S14-S80, 2014.

2- AMUTHA A., THAI K. and VISHWANATHAN M.: Chilhood and adolescent onset Type 1 diabetes in India. J. Med. Sci., 1 (1): 46-53, 2013.

3- CARDA C., MOSQUERA-L. LOREDA N., SALOM L., GOMEZ De FERRARIS M.E. and PEYDRO A.: Structural and functional salivary disorders in type 2 diabetic patients. Med. Oral Patol. Oral Cir. Bucal., 11 (4): E309-E314, 2006.

4- HEDGE A., SHENOY R., D'MELLO P., SMITHA A. TINTU A. and MANJREKAR P.: Alternative markers of glycemic status in diabetes mellitus. Biomed. Res., 21: 252-6, 2010.

5- GOLDSTEIN D.E., LITTLE R.R., WIEDMEYER H.M., ENGLAND J.D. and McKENZIE E.M.: Glycatedhemoglbolin: Methodologies and clinical applications. Clin. Chem., 32: B64-B70, 1986.

6- ISPAD Clinical Practice Consensus Guidelines Compendium: Assesment and monitoring of glycemic control in children and adolescents with diabetes. Pediatric Diabetes, 15 (20): 102-14, 2014.
7- BRADFORD M.M.: A rapid and sensitive method for the quantitation of microgram quantities of protein utilizing the principle of protein-dye binding. Anal. Biochem., 72 (1-2): 248-54, 2011.

8- PANCHBHAI A.S., DEGWEKAR S.S. and BHOWTE R.R.: Estimation of salivary glucose, salivary amylase, salivary total protein and salivary flow rate in diabetes in India. J. Oral Sci., 52: 359-68, 2010.

9- GHEENA S., CHANDRASHEKHAR T. and RAMANI P.: Salivary characteristics of diabetic children. Braz J. Oral. Sci., 10: 93-7, 20110.

10- The Expert Committee onthe Diagnosis and Classification of Diabetes Mellitus: Report of the expert committee on the diagnosis and classification of diabetes mellitus. Diabetes Care, 25 (1): S5-S20, 2002.

11- KRISHNA B.A., ASHALATHA G., BAGHIRATH V.P. RAJANIKANITH A.V. and MALATHI N.: Saliva as a diagnostic biofluid-review. J. Orofac. Sci., 2: 66-70, 2010.

12- LOPEZ M.E., COLLOCA M.E., PAEZ R.G., SCHHALLMACH J.N., KOSS M.A. and CHERVONAGURA A.: Salivary Characteristics of diabetic children. Braz. Dent. J., 14 (1): 26-31, 2003.

13- ABIKSHYEET P., RAMESH V. and OZA N.: Glucose estimation in the salivary secretion of diabetes mellitus patients. Diabetes Metab. Syndr. Obes., 5: 149-54, 2012.

14- SHAHBAZ S., KATTI G., GHALI S.R., KATTI C., DIWAKAR D.D. and GUDUBA V.: Salivary alteration in type 1 diabetes mellitus patients: Salivary glucose could be noninvasive tool of monitoring diabetes mellitus. Indian J. Dent. Res., 25: 420, 2014.

15- NAGALAXMI V. and PRIYANKA V.: Can saliva be a marker for predicting type I diabetes mellitus?-a pilot study. J. Indian Acad. Oral. Med. Radiol., 23 (4): 57982, 2011.

16- IQBAL S., ASAD S., FARHAT K. and FAREEHA B.: Correlation between salivary glucose level and gingivitis in patients with diabetes. J. Islamabad. Med. Dent., 1103, 2011 .

17- FORBAT L.N., COLLINS R.E., MASKELL G.K. and SONKSEN P.H.: Glucose concentrations in parotid fluid and venous blood of patients attending a diabetic clinic. J. R. Soc. Med., 74 (10): 725-8, 1981.

18- YAVUZYILMAZ E., YUMAK O., AKDOGANLI T., YAMALIK N., OZER N., ERSOY F., et al.: The alteration of whole saliva constituents in patients with diabetes mellitus. Aust. Dent. J., 41: 193-7, 1996.

19-BEN-ARYEH H., SEROUYA R., KANTER Y., SZARGEL R. and LAUFER D.: Oral health and salivary composition in diabetic patients. J. Diabetes Complications, 7: 57-62, 1993.

20- BELAZI M.A.,GALLI-TSINOPOULOU A., DRAKOULAKOS D., FLEVA A. and PAPANAYIOTOU P.H.: Salivary alteration in insulin dependent diabetes mellitus. Int. J. Paediatr. Dent., 8: 29-33, 1998.

21- SREEDEVI L., SHASHIKANTH M.C. and SHAMBULINGAPPA P.: Comparison of serum glucose and salivary 
in diabetic patients. J. of Indian Academy of Oral Medicine and Radiology, 20 (1): 9-13, 2008.

22- JURYSTA C., BULUR N., OGUZHAN B., et al.: Salivary glucose concentration and excretion in normal and diabetic subjects. J. Biomed. Biotecnol., 2009: 430426, 2009.

23- BAKIANIAN-VAZIRI P., VAHEDI M., MORTAZAVI H., ABDOLLAHZADEH SH. and HAJILOOI M.: Evaluation of salivary glucose, $\operatorname{IgA}$ and flow rate in diabetic patients: A case-control study. J. Dent. (Tehran), 7: 138, 2010.

24- American Diabetes Association: Standards of medical care in diabetes. Diabetes Care, 34 (1): 11-61, 2011.

25- SATISH B.N., SRIKALA P., MAHARUDRAPPA B., AWANTI S.M., KUMAR P. and HUGAR D.: Saliva: A tool in assessing glucose levels in Diabetes Mellitus. J. Int. Oral Health, 6 (2): 114-7, 2014.

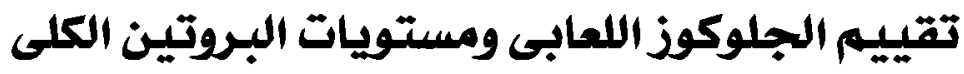 لدى الآطفال المصابين بلداء السكرى من النوع الآول}

داء السكرى هو مجموعة من الآمراض الإستقلابية التى تتميز بإرتفاع السكر في الدم الناتج عن عيوب إفراز الآنسولين، عمل الآنسولين

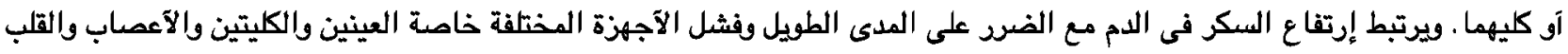
والآوعية الدموية.

اللعاب هو سائل فريد من نوعه فهو يفسل بإستمرار الفشاء المخاطى لتجويف الفم والبلعوم فهو خليط معقد مستمد من إفراز الغدد اللعابية.

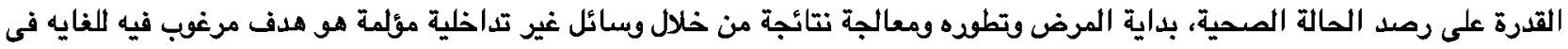

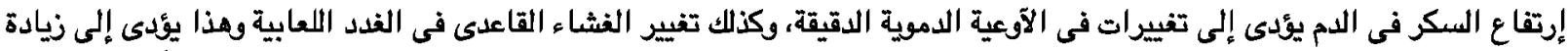

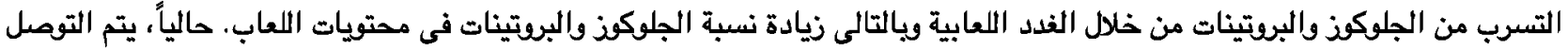

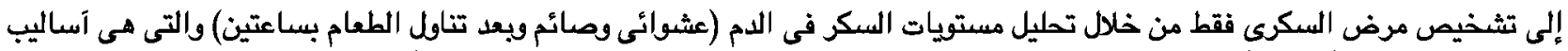

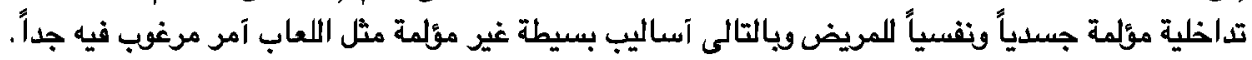

الهدف من الدراسة: هو قياس مستويات السكر وإجمالى البرتين في اللعاب حتى يتم إستخدام اللعاب كوسيلة غير مؤلمة لتشخيص ومتابعة

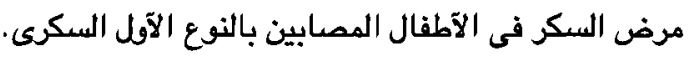

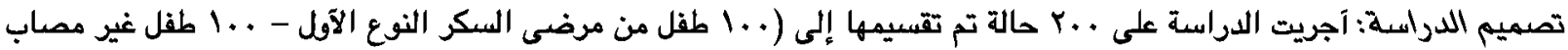

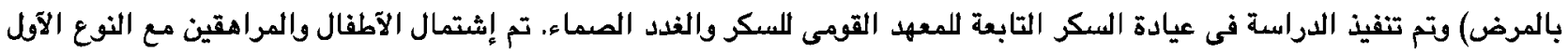

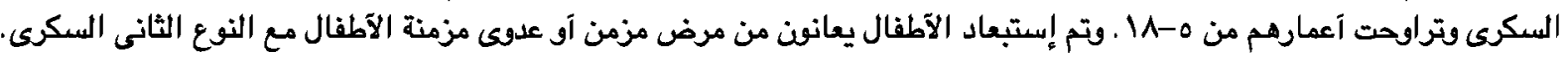

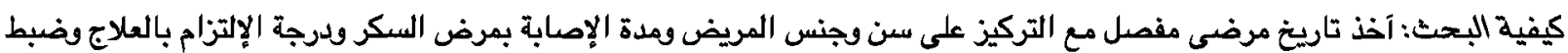

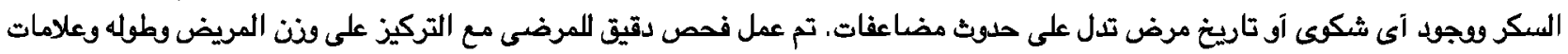
ترجح حدوث أى مضاعفات.

إشتملت الفحوصات المعملية على قياس (مستويات السكر بالدم - مستوى الهيموجلويين السكرى - مستوى الجلوكوذ فى اللعاب - مستوى إجمالي البرتين فى اللعاب).

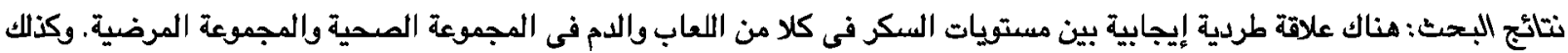

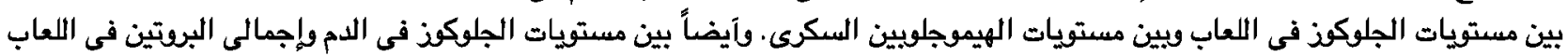
وبين مستويات الجلوكوذ في اللعاب وإجمالى البرتين في في اللعاب.

لذا نستخلص من هذه الدراسة آن اللعاب يمكن آن يستخدم كوسيلة غير مؤلمة وغير تداخلية لتشخيص ومتابعة مرض السكرى النوع الآول. 